\title{
Analysis on Apple's Implement and Assessment of Dividend Policy
}

\author{
Lin Lixing ${ }^{1}$ \\ ${ }^{1}$ Haidian Foreign Language International School, Beijing, China
}

\begin{abstract}
Dividend policy is a means that a company uses to distribute its free cash to its shareholders. It is of importance step to determine how much free cash will be retained for firm growth and how much for shareholders. This article first examines financial conditions in Apple and Samsung in recent years. With the financial information, the article display how Apple make decision on its dividend policy. Also, relevant data are provided in charts and tables to analyze trajectory of Apple's dividend policy which are proved by later data. By comparing it with Samsung in dividend policy, readers are able to see how financial circumstances effect decisions making. As a result, Apple aims to hold a sustainable dividend payouts growth rate because financial risks will be minimized and more free cash can be used to invest in firm growth, such as technological innovation; however, Samsung aims to attract more investors and specialists, so it provides a lucrative dividend policy by increasing its dividend payouts rate. This will be at expense of Samsung's future investment on firm growth.
\end{abstract}

\section{INTRODUCTION}

For this article, it analyzes in which way a typical company, Apple, will implement and assess its dividend policy. It is pivotal for Apple to set a predictable dividend policy for its shareholders and new investors. In order to concordance with its trajectory, Apple needs to predict future trends of dividend growth. Apple went public on December 12, 1980, and hit a record market value of $\$ 623.5$ billion in 2012. This was brought by the rapid growth inside the Apple company, and it has impeccable dividend policies. Samsung went public in 1989 and was worth $\$ 150$ billion in 2011. This is related to dividend policies through paying out and retaining. Of course, these policies will have sort of impact on interest growth since companies need to decide how much funds and interests will be retained for company's growth, called retained profits, which are of importance for the interest growth in the future. Apple and Samsung are two technology companies, and they both have experienced rapid growth rates, so they should have strategies on dividend policies to facilitate the rates. In the research, we collect the data from Apple and Samsung's annual reports and other materials related to those two companies' dividend policies.

\section{Historical FinANCIAL DATA}

More net cash flow means more free cash to invest or retain, so managing free cash is of importance for both companies.

\subsection{Data collection}

In order to analyze the financial information in Apple, the study researched and collected the data and table of cash flow and dividend history.[1]

\subsection{Apple Cash Flow Statement}

In this study, free cash will be used to determine available cash for shareholders and firm growth after all expenses are paid. "They state that cash flow is a major determinant of the firm's dividend payout policy and should therefore be included." [3]

This statement is annual data in millions of U.S. dollar after taking apart the part from 2014 to 2019 to correspond to following discussion. From Table 1, net cash flow has fluctuated, but mostly it is positive; some of negative numbers of net cash flow is subtle. Also, common stock dividends paid increased continuously which means Apple experienced a stable financial growth and shareholders get mounting return on their investment and equity.

\subsection{Samsung Cash Flow Statement}

The annual data in millions of KRW is showed in table 2 . The article takes the part from 2015 to 2019.

As table 2 shows: it is true that Samsung has great positive number of net financing cash flow through 2015 to 2019 , but its growth rates from 2016 to 2018 are negative. Also, cash dividend paid grew rapidly from 
2015 to 2018, but experienced adversely growth in 2016 and 2019, which means that Samsung's dividend paid was not stable but it plans to increase its dividend to attract more investors.

\subsection{Comparison between Apple and Samsung Cash Flow}

In past few years, obviously, Apple had a sustainable growth in its return on equity since dividend paid was increasing continually. However, Samsung had a negative number on its dividend paid in 2016 and 2019. Therefore, in the aspect of net cash flow, Apple has a better financial condition than Samsung.

TABLE 1. Simplified Apple's AnNual CASh Flow[1]

\begin{tabular}{|l|l|l|}
\hline Date & $\begin{array}{l}\text { Net cash } \\
\text { flow }\end{array}$ & $\begin{array}{l}\text { Common stock dividend } \\
\text { paid }\end{array}$ \\
\hline $2019-9-30$ & 24,311 & $-14,119$ \\
\hline $2018-9-30$ & 5,624 & $-13,712$ \\
\hline $2017-9-30$ & -195 & $-12,769$ \\
\hline $2016-9-30$ & -636 & $-12,150$ \\
\hline $2015-9-30$ & 7,276 & $-11,561$ \\
\hline $2014-9-30$ & -415 & $-11,126$ \\
\hline
\end{tabular}

TABLE 2. Simplified SAmsung's Annual Cash Flow[2]

\begin{tabular}{|l|l|l|l|}
\hline Year & $\begin{array}{l}\text { Net } \\
\text { Financing } \\
\text { cash flow }\end{array}$ & $\begin{array}{l}\text { Net } \\
\text { Financing } \\
\text { cash flow } \\
\text { growth }\end{array}$ & $\begin{array}{l}\text { Common stock } \\
\text { dividend paid }\end{array}$ \\
\hline 2019 & $9,482,810$ & $37.19 \%$ & $9,639,202$ \\
\hline 2018 & $15,098,293$ & $-20.15 \%$ & $10,193,695$ \\
\hline 2017 & $12,566,537$ & $-44.73 \%$ & $6,804,297$ \\
\hline 2016 & $8,682,746$ & $-32.60 \%$ & $3,114,742$ \\
\hline 2015 & $6,548,197$ & - & $3,129,544$ \\
\hline
\end{tabular}

\section{APPLE'S DIVIDEND POLICY DECISION}

\subsection{Retained Earnings and Dividend Payouts}

How a company manages the free cash flow is important. The free cash can be used for retained earnings and dividend payouts. Therefore, pros and cons to retained earnings and dividend payouts need to be discussed. There is a negative relationship between dividend payouts and firm growth, which is benchmark for this discussion. "The most commonly used explanation for the negative relationship between the dividend payout ratio and growth is that growing companies have to finance parts of the increased investments by retained earnings." [3] Therefore, if a company increases its dividend paid, this decision adversely affects firm's growth, since more cash are paid to shareholders. On the one hand, companies with higher growth rate will decrease their dividend payouts since they will have a higher level of retained earnings. On the other hand, companies with lower growth rate will increase their dividend payouts, having a lower level of retained earnings.

\subsection{Apple's Dividend Strategy}

Define abbreviations and acronyms the first time they are used in the text, even after they have been defined in the abstract. Abbreviations such as IEEE, SI, MKS, CGS, sc, $\mathrm{dc}$, and rms do not have to be defined. Do not use abbreviations in the title or heads unless they are unavoidable.

First, Apple's historical dividend growth is needed to be look through. Apple has increased its quarterly cash dividend annually beginning in 2012. By looking at the trend of quarterly dividend growth rate, Apple managed to increase quarterly dividend by nearly $10 \%$. Meanwhile, Apple implemented share buybacks, which made it cheaper for Apple to pay higher cash dividends per share, since the number of outstanding shares reduced. Even though Apple bought back its outstanding shares, raising the quarterly dividend will be beneficial for shareholders, so Apple still has greater leverage.On the surface, the dividend growth is approximately $10 \%$, but actually, the growth in Apple's dividend expenses has only 5\% due to the share buybacks (the number of shares decreased). In fact, in following years, Apple's dividend payouts will fluctuate around $5 \%$, ranging from $2 \%$ to $10 \%$, trending a increasingly sustainable growth rate.

\subsection{Dividend Sustainability}

By judging the sustainability, the article will examine Apple's dividend payouts ratio which shows the percentage of cash dividend over Apple's net income. Apple's dividend payout ratio declines from $29 \%$ to $21 \%$ (2013-2015), the lowering dividend payout ratio means a sustainable growth inside Apple, since Apple will have more retained earnings as mentioned in 3.1 retained earnings and dividend payouts. Apple has more cash to more cash to operate and invest new projects to firm's growth, meaning it has a greater growth potential. Although Apple had boost earnings in 2014 and 2015, its dividend expenses growth rate still maintained at $5 \%$. For one thing, Apple expected to avoid the dividend payouts fluctuation in the future, since conflicts between shareholders would occur when dividend payouts decrease (shareholders gain benefits through dividend payouts). Thus, if there was a sustainable growth, investors would predict a great long-term view for dividend payouts in Apple. Also, management group in Apple aims to keep dividend payouts growth rate consistent, because the rate does not fluctuate with business cycle, in order to make sure the safe operation in Apple's finance.

\subsection{Apple's Dividend Trajectory}

Finally, we are going to examine how Apple assessed their prospect to its dividend policy. We will chart the historical data for Apple's dividend trajectory, in order to predict the future condition of dividend expenses in Apple. We assume Apple's dividend payouts growth rate is 5\% since it has a stable dividend policy. There are two other 
scenarios in Fig.1 and Fig.2: green line represents 10\% growth rate and red line represents $2 \%$ growth rate.

The study will show past dividend path prediction. Given that Apple increases its dividend expenses by $5 \%$ each year, in 2016, it could reach 12.2 Billion dollars. In 2019 , it could be up to 14.8 Billion dollars, which is an expected dividend path for 5\% annual growth in dividend expenses. Converting the result to quarterly per share, the number was end up with 0.58 dollar in 2016 and 0.82 dollar in 2019, continuously growing from 2016 to 2019 .

Most importantly, Apple operated in a business environment, so the management group in Apple needs to reevaluate the profitability in the industry.

Therefore, when dividend payouts path is not on the expected trend,as Fig. 2 shows, if it is above the blue line (in green shadow area), then it can be called positive trend; if it is under the blue line (in red shadow area), then negative trend.

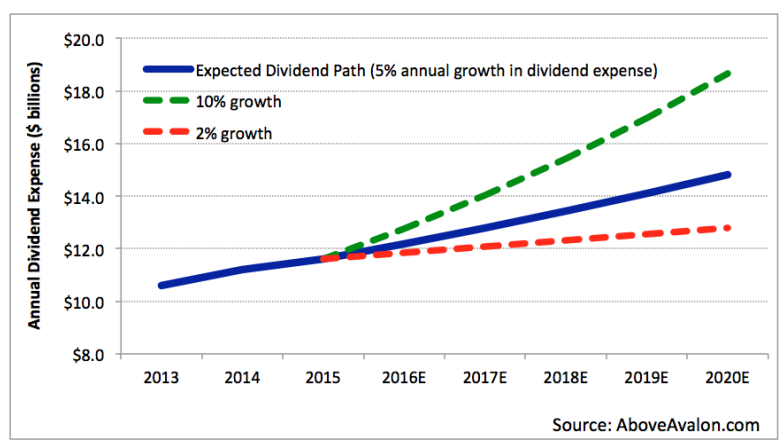

Figure 1. Apple Annual dividend expenses[4]

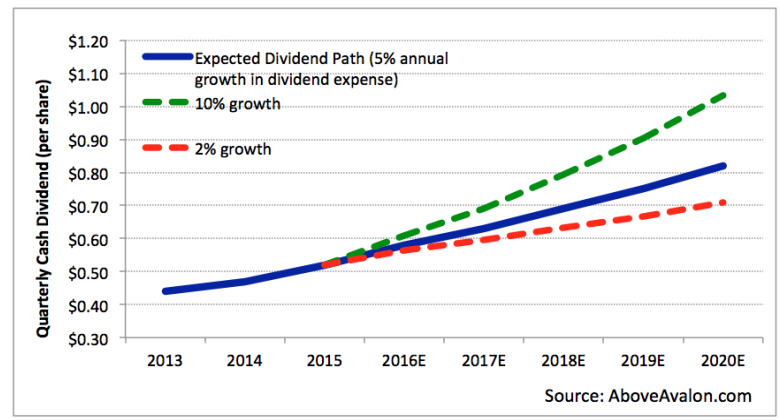

Figure 2. Quarterly Apple Annual dividend expenses [4]

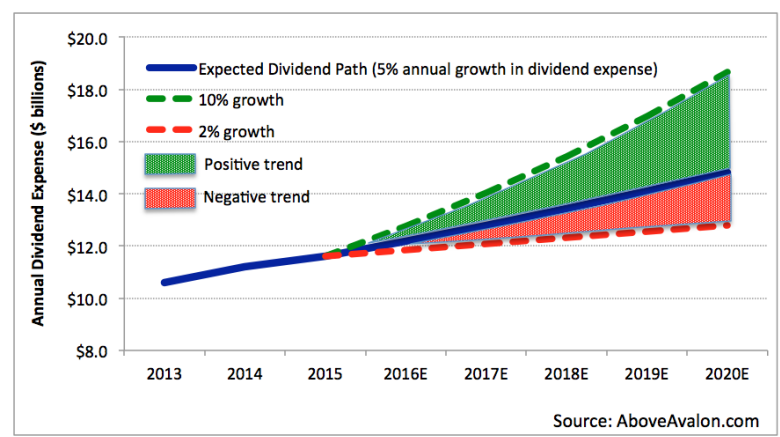

Figure 3. Apple Expected Dividend Path[4]

From Fig.4, at the beginning of 2018, Apple declared share for 0.63 dollar which was at the red zone, so Apple reduced its dividend expectation. In 2019, Apple increased its dividend expectation in green zone.
Therefore, Apple wanted to slow down the dividend growth rate in 2018; in 2019, Apple wanted to attract relatively more investors or fulfill shareholders' demand (return on investment).

\begin{tabular}{lllll} 
October 30, 2019 & November 11, 2019 & November 14, 2019 & $\$ .77$ & Regular Cash \\
\hline July 30, 2019 & August 12, 2019 & August 15, 2019 & $\$ .77$ & Regular Cash \\
\hline Apr 30, 2019 & May 13, 2019 & May 16, 2019 & $\$ .77$ & Regular Cash \\
Jan 29, 2019 & Feb 11, 2019 & Feb 14, 2019 & $\$ .73$ & Regular Cash \\
\hline Nov 1, 2018 & Nov 12, 2018 & Nov 15, 2018 & $\$ .73$ & Regular Cash \\
\hline Jul 31, 2018 & Aug 13, 2018 & Aug 16, 2018 & $\$ .73$ & Regular Cash \\
\hline May 1, 2018 & May 14, 2018 & May 17, 2018 & $\$ .73$ & Regular Cash \\
\hline Feb 1, 2018 & Feb 12, 2018 & Feb 15, 2018 & $\$ .63$ & Regular Cash
\end{tabular}

Figure 4. Apple dividend history[5]

\section{COMPARISON WITH SAMSUNG}

\subsection{Samsung dividend policy}

"The Board of Directors of Samsung C\&T Corporation approved the Company's three year dividend policy for 2017-2019, which includes a significant increase in annual dividend payments." [6] The company will increase the annual dividend up to 2,000 won per share, which is approximately 4 times the company paid in 2016 With increasing dividend payouts, shareholders in Samsung can gain more from this policy. Therefore, in order to fulfill the expectation in high return on shareholder returns, providing more dividend payouts and predictable returns. Also, the board of directors of Samsung is considering to nominate new directors who have talents and expertise in the industry.

"Samsung Electronics remains committed to delivering sustainable shareholder value and will continue to enhance long-term value creation". [7] This sustainable return for shareholders will attract and bring confidence for new investors. "Samsung said last year it will commit 50 per cent of its free cash flow to shareholders for 2016 and 2017." [7]However, if those free cash flows are distributed to increasing dividend payouts, the retained earnings will decrease. As a result, Samsung's new technological program will be ceased, like Samsung Galaxy series development and research.

\subsection{Comparisons between Apple and Samsung' Dividend Policy}

Apple has amassed 51 billion dollars recently, and some investors ask for more returns. However, because of Apple's sustainable dividend policy, it reluctantly changes its dividend policy, and it aims to build funds for future growth. [8] However, Samsung doubled its dividend paid to attract more investors, "but investors point out that is still half of Apple's 2.0 percent"[8].

Therefore, Robert Li announced that Samsung planned to increase its dividend payouts significantly in recent 
years to keep pace with Apple. In short, Apple has a stable dividend policy, aiming to have a sustainable growth in dividend payouts considering future growth; Samsung aims to attract more independent investors and specialist by increasing dividend paid significantly.

\section{Conclusion}

For apple, mentioned in 3.4, The trajectory of Apple's dividend payouts is clearly shown and predicted.All shareholders and investors can get information from Apple to judge the return ratio in Apple in current year. To make sure a sustainable firm growth, Apple has to maintain the stable growth rate in dividend payouts. However, Samsung plans to attract more investors and specialists in electronic field, but it distributes almost half of its free cash into dividend paid. Therefore, Apple and Samsung have completely different strategies toward dividend policy: Apple aims to have stable growth rate in dividend policy in order to retain more free cash for firm growth; Samsung aims to attract more directors and investors by increasing return ratio.

Various researchers have argued that the size of the company is one of the factors that have the largest influence on the dividend payout ratio. [3] Considering the size, Apple has less risk and diverse shareholders, so Apple only has to maintain current circumstance by keeping a stable and sustainable growth. For Samsung, it does not have diverse shareholders and large scale, which means it has to take more risks than Apple. Therefore, Samsung has made a correct decision to expand its board of directors by attracting new investors and specialists.

\section{ACKNOWLEDGMENT}

First of all, I would like to thank Professor Sun for his careful guidance and teachings. The subject I learned is not simple, and it covers a wide range of knowledge. When we could not absorb directly, she explained the confusing points step by step so that we could have a good understanding when we wrote the paper later. Secondly, I would like to thank my team partners. In the PPT making process, we help each other. They all gave me the most help when I asked some questions. Here, I sincerely thank them for their support and help.

\section{REFERENCES}

1. Apple Cash Flow Statement 2005-2020: AAPL

2. SSNLF | Samsung Electronics Co. Ltd. Annual Cash Flow - WSJ

3. Gustav Hellström (Spring semester2012), Determinants of Dividend Payout Ratios. https://www.divaportal.org/smash/get/diva2:538687/fulltext02

4. Examining Apple's Dividend Strategy, April 13, 2016, https://www.aboveavalon.com/notes/2016/4/13/exa mining-apples-dividend-strategy
5. Dividend History, July 25, 2020, https://investor.apple.com/dividendhistory/default.aspx

6. Samsung C\&T Announces Enhanced Dividend Policy for 2017-2019, January 09, 2018, https://news.samsungcnt.com/samsung-ctannounces-enhanced-dividend-policy-2017-2019/

7. Subscribe to the FT to read: Financial Times Samsung Electronics plans more than $\$ 25 \mathrm{bn}$ in dividend returns, July 26, 2020, https:/www.ft.com/content/5607402f-b128-302082bd-a1f2e11663d0

8. Samsung Electronics pledges higher dividend after record payout, January 24, 2014, https://www.reuters.com/article/uk-samsungearnings/samsung-electronics-pledges-higherdividend-after-record-payoutidUKBREA0N00020140124 